\title{
DO BOT FLIES, CUTEREBRA (DIPTERA: CUTEREBRIDAE), EMASCULATE THEIR HOSTS?
}

\author{
Robert M. Timm ${ }^{1}$ and Richard E. Lee, $\mathrm{Jr}^{2}$
}

\begin{abstract}
Asa Fitch, in his description of a new species of Cuterebra that he named "emasculator," was the first to suggest that bot flies castrated their mammalian hosts. In recent years several major review papers and parasitology texts have continued to perpetuate this belief. A review of both the literature on bot flies and their hosts and of the life cycles of both bots and hosts provides no evidence to substantiate castration. Eastern Chipmunks (Tamias striatus) experimentally infected with $\mathrm{Cu}$ terebra emasculator experienced no destruction of testicular tissue. The concept of castration may have been perpetuated by observations of bots in the scotal sac of a host. Superficial examination of a host with a bot(s) in the scrotum would suggest that the bot had consumed the testis; this is demonstrated on a White-footed Mouse (Peromyscus leucopus). We conclude that there is no evidence to support the notion that bot flies castrate their mammalian hosts. On extremely rare occasions, a bot may slightly displace a testis, and perhaps this temporarily reduces fertility.
\end{abstract}

The first published reference to bot flies of the genus Cuterebra (Diptera: Cuterebridae) castrating their hosts was by Fitch (1857: 482). He wrote that "the fact is well known to hunters, that of the grey and other squirrels killed in this vicinity, at least one half of the males are castrated. It is the current opinion with them that this deformity is caused by the squirrels' seizing and biting out the testicles of their comrades, some of them strenuously maintaining that they have seen these animals engaged in this act. There are some hunters, however, that say they have found two grubs in the scrotum of some squirrels, and they conjecture that it is by these that the testicles are destroyed...." $\mathrm{He}$ went on to say that "I am therefore led to believe that these animals do attack each other in the manner that has been stated; not, however, for the purpose of emasculating their comrades, as has been supposed, but for the purpose of coming at and destroying these bot-grubs, the enemies of their race." Fitch concluded: "I think that every one will agree with me in the opinion that it is by this fly

\footnotetext{
${ }^{1}$ Bell Museum of Natural History, University of Minnesota, Minneapolis, Minnesota 55455, USA. Present address: Division of Mammals, Field Museum of Natural History, Roosevelt Road at Lake Shore Drive, Chicago, Illinois 60605, USA.

${ }^{2}$ Department of Biology, University of Houston, Houston, Texas 77004, USA.
}

that the squirrels in our country are emasculated." Fitch named the chipmunk bot Cuterebra emasculator to reflect this belief. For the next 63 years, it remained established dogma that bot flies castrated their male hosts; the mechanism was thought to be total consumption of the testes. Ernest Thompson Seton, the famed naturalist, was the first to question whether bot flies actually do emasculate their rodent hosts. Seton (1920: 95) stated that "There is no proof that the bot eats fibrous tissue, or anything but juices," and ". . . at the season of all observations-August, September, and October - the testes are normally reduced to almost nothing, drawn into the pelvis." Seton also noted that bots are just "as often found in other parts of the body, and in the female as much as in the male." Seton's doubts about castration were not confirmed at the time and most subsequent authors have ignored his paper.

In recent years, several major review papers and texts have continued to perpetuate the belief that bot flies totally castrate their hosts, thereby effectively reducing the parasitized individual's future reproductive potential to zero (for example, see: Askew 1971: 263, Baudoin 1975, Cameron 1956: 184, Caullery 1952, Chandler \& Read 1961: 789, Cheng 1973: 844, Dalmat 1942, Krull 1969: 341, Noble \& Noble 1976: 429). A typical quote from a recent parasitology text (Cheng 1973: 844) concerning host castration by Cuterebra makes this blanket statement, with no reference cited: "Cuterebra emasculator can destroy its host's testes, causing parasitic castration." Krull (1969: 341) stated "There is one species in the squirrel [presumably C. emasculator] that lives habitually in the scrotum, destroys the testicles, and emasculates the host." Thus, this concept has been so thoroughly ingrained in the literature for the past 124 years that beginning students are taught it as a matter of fact.

Although a number of papers have been cited in support of host castration by bot flies (Bennett 1955, Goertz 1966, Hunter et al. 1972, Wecker 1962), none provides clear-cut evidence for host castration. Wecker (1962: 563) suggested that the 
presence of a bot fly in the inguinal region "could offer mechanical interference with the descent of the testes," but there is no mention of bot flies destroying testicular tissue. Hunter et al. (1972: 28) make absolutely no mention of host castration by bot flies on the White-footed Mouse, Peromyscus leucopus, but did conclude that "There is, therefore, no evidence for the botfly causing significant deermouse mortality." Goertz (1966) also made no mention of host castration. Even though Bennett (1955: 75) is frequently cited in support of host castration, he stated in his abstract that "No case of emasculation was noted."

Numerous theories concerning the parasite's "castration strategies" have been based on these supposed "facts." We were prompted to write this paper because, to our knowledge, all available data support the opposite hypothesis: that bots have little effect upon the testes. First, we will briefly summarize the life history of Cuterebra emasculator, the bot fly parasitizing the Eastern Chipmunk (Tamias striatus) and the one most frequently accused of castrating its host, based upon our field and laboratory work in Minnesota and that of Bennett $(1955,1972 a, b, 1973)$ in Ontario. Second, we will summarize the observed effects of Cuterebra on their hosts.

\section{Life history of Cuterebra emasculator}

Although rarely observed in the field, the adult bots emerge, mate, and oviposit during midsummer. As in other Cuterebra (see Capelle 1971), females probably oviposit along runways and burrows of the hosts, with no direct contact between the gravid female bot fly and the host. Egg hatching is triggered by a sudden rise in environmental temperature as would occur near a potential host. After hatching, the 1st-instar larvae assume a "questing position" by standing on their caudal ends and attach quickly to any object coming in contact with them. It is believed that the larvae crawl over the body of the host and are only able to enter through a natural body orifice. For 7 to 10 days after entering through the nose or mouth, the larvae migrate dorsally and medially between the skin and muscle layers until the breathing hole is cut, marking the site of warble formation. The larvae are typically located in the posterior $1 / 3$ of the abdomen, although they are occasionally found on the neck, back, flank, and between the forelegs. Commonly 1-3 larvae are found per host, with similar infection rates for male and female chipmunks. Peak infections occur from mid-Au- gust through mid-September. Larval development is completed in $3 \frac{1}{2}$ weeks, when 3rd-instar larvae emerge through the breathing hole, burrow into the soil and pupate, overwintering in the puparium.

\section{Effects of Cuterebra on hosts}

Despite the fact that the combined weight of the bot fly larvae in multiple infections may constitute $3-5 \%$ or more of the body weight of the chipmunk, there appears to be little impairment during infestation or marked long-term effect after emergence. Infected hosts, including 1 naturally infected chipmunk from which 11 bots later emerged, appeared to forage normally as compared to noninfected individuals. One of our juvenile chipmunks increased its body weight by $124 \%$ (42.4 to $94.9 \mathrm{~g}$ ), during which time it "produced" 6 bots. The larval cyst is found only in the subcutaneous layer and does not invade underlying muscles or organs. Shortly after larval emergence, the larval cyst collapses and heals rapidly. At 1 week postemergence it may be difficult to locate the exact site of the former breathing hole.

In northern regions, chipmunks reproduce primarily in the spring (Bennett 1955, Forbes 1966, Pidduck \& Falls 1973) and bot fly infestations occur in mid- to late summer; thus there is little or no overlap between reproduction in chipmunks and peak infestation by bots. Therefore, during the time of most infestations, testes of male chipmunks are normally reduced and ascended into the abdomen. The testes of 2 chipmunks were examined after 4 and 6 bot fly larvae had emerged from cysts in the scrotal region. A 3rd male died after being artificially infected with 19 bot fly larvae that were located in an extensive pouch covering the entire inguinal area including the scrotum. In all 3 males, the larvae were found only subcutaneously and did not invade the underlying muscle. Furthermore, the ascended testes appeared normal and undamaged. Bennett (1955) examined 34 larvae located subcutaneously in the scrotal region of several chipmunks and found that none had penetrated the muscle layer into the scrotum. However, as the larvae matured the cyst commonly bulged into the scrotal sac.

In Fig. 1 an adult male White-footed Mouse (Peromyscus leucopus noveboracensis) from south-central Minnesota is shown. A bot fly larva (Cuterebra sp., probably fontinella Clark) is located in the inguinal region of this mouse. Notice that the left side of the scrotum is enlarged and light in color. 


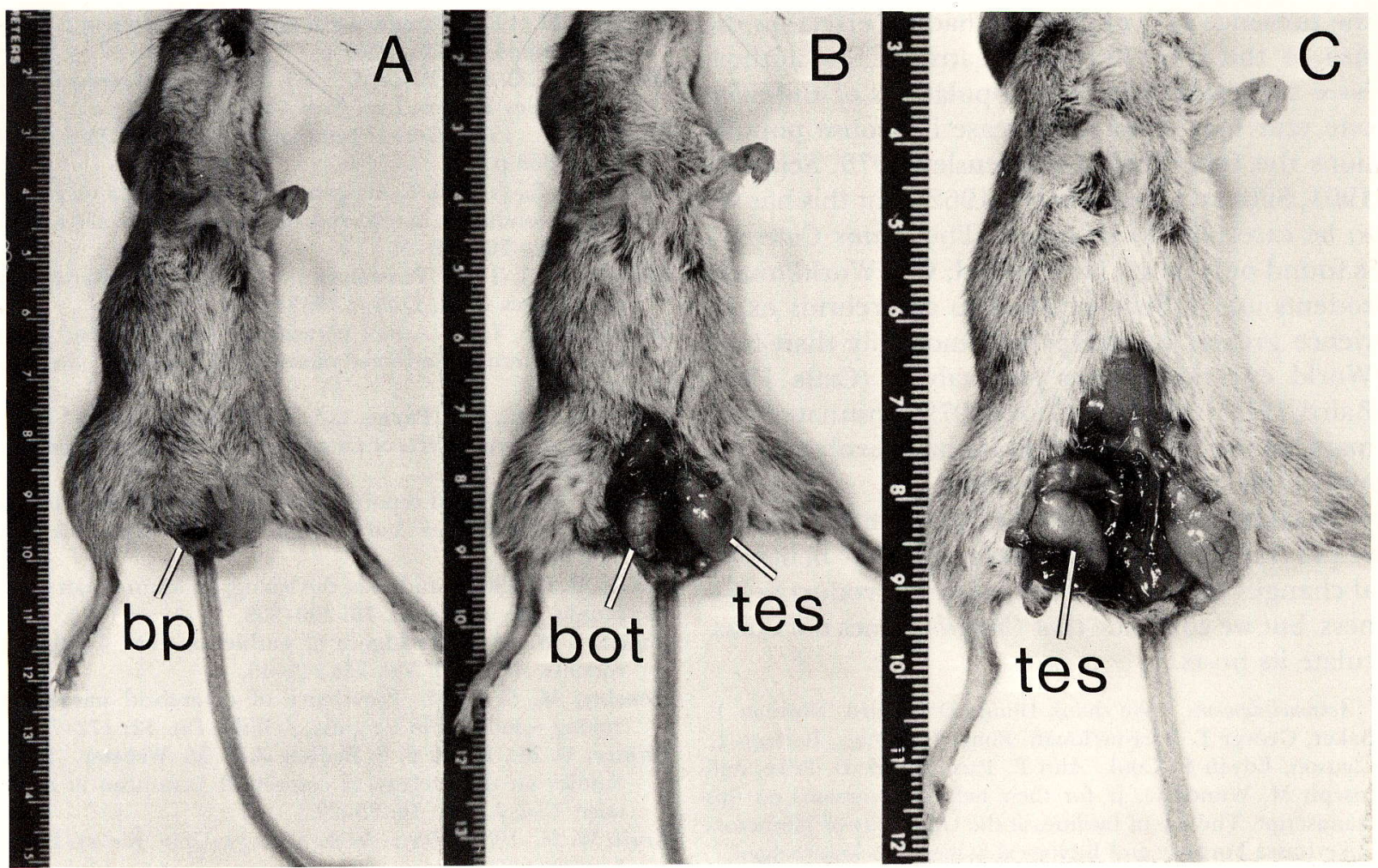

Fig. 1. An adult male White-footed Mouse, Peromyscus leucopus noveboracensis, with a single bot fly larva (Cuterebra sp., probably fontinella) located in the scrotal region. A: The open breathing pore (bp) cut by the bot can be seen in the right scrotum; the left scrotum is enlarged, typical of mice in breeding condition. B: Removing the skin and underlying muscle layer reveals the larval bot (bot) opposite the left testicle (tes). C: The right testicle is entirely intact, but has been slightly displaced by the bot.

Just beneath the skin is an enlarged testicle, typical of mice in breeding condition. The right side of the scrotum is not enlarged and is darker. Beneath the skin on the right side is a bot fly larva. Its placement in this particular mouse is exactly opposite the left testicle and the right testicle is not visible; thus it appears as if the bot has consumed the right testis. However, a closer examination reveals that the right testis is present, but has been slightly displaced (dorsally) by the bot. The length, width, and weight of both testicles were identical $(14 \times 9 \mathrm{~mm}$, $0.5 \mathrm{~g}$ ). Both the left and right epididymis contained viable sperm and were highly convoluted. The right testis did show increased vascularization in the area adjacent to the bot fly larva. A superficial examination of this mouse would have suggested that the bot emasculated its host; however, both testes were present and producing sperm.

Cryptorchidism, or undescended testes, may result in lowered fertility (see Baudoin 1976); however, this probably is not a major factor in bot fly parasitism. It is unusual for a testis to be displaced as much as the one shown in Fig. 1. Generally, the testes retain their normal position in the scrotum.

Bot fly larvae have physiological effects on their hosts. Significantly lower erythrocyte counts, hematocrit percentages, albumin-globulin ratios, and hemoglobin concentrations were found in mice parasitized by cuterebrid larvae, while the leucocyte number, spleen size, and thymus size were significantly larger (see Bennett 1973, Childs \& Cosgrove 1966, Clough 1965, Dunaway et al. 1967, McKinney \& Christian 1970, Payne et al. 1965, Selander 1961, Timm \& Cook 1979). Tissue damage by Cuterebra was reported by Payne \& Cosgrove (1966), but they found healing and repair of damaged tissue to be rapid once the bot emerged. Smith (1977) reported a reduction in testes size in Deer Mice (Peromyscus maniculatus) artificially infected with Cuterebra. Timm \& Cook (1979) demonstrated that, in adult female White-footed Mice parasitized by Cuterebra fontinella, there was no significant decrease in the number of embryos, corpora lutea, or placental scars; in adult male mice 
the presence of 1 or 2 larvae had no effect on the size of the reproductive organs. A few authors have suggested that high populations of Cuterebra one year may cause a decrease in mouse populations the following year (Hensley 1976, Selander 1961, Sillman 1955, Wecker 1962), but this has yet to be carefully documented. The genus Cuterebra is found only in the New World; Old World murid rodents and rabbits exposed to cuterebrids experience greater hardships and mortality than New World cricetid rodents and rabbits (Catts 1965, Baird 1979). Timm \& Cook (1979) postulated that many of the New World hosts have evolved a tolerance for cuterebrid parasitism.

To summarize, costs to the host of added energy requirements and other physiological or behavioral changes may or may not lower reproductive fitness, but we conclude that Cuterebra does not emasculate its hosts.

Acknowledgments. We thank Donna Day Baird, Norman T. Baker, George F. Barrowclough, Elmer C. Birney, Barbara L. Clauson, Edwin F. Cook, Ann E. Pace, Roger D. Price, and Joseph M. Wunderle, Jr for their helpful comments on this manuscript. The use of facilities at the University of Minnesota Lake Itasca Forestry and Biological Station is acknowledged.

\section{LITERATURE CITED}

Askew, R. R. 1971. Parasitic insects. American Elsevier Publishing Company, Inc., New York. 316 p.

Baird, C. R. 1979. Incidence of infection and host specificity of Cuterebra tenebrosa in bushy-tailed wood rats (Neotoma cinerea) from central Washington. J. Parasitol. 65: 639-44.

Baudoin, M. 1975. Host castration as a parasitic strategy. Evolution 29: 335-52.

1976. The cost of reproduction in the white-footed mouse Peromyscus leucopus, with reference to the effects of parasitic castration by the botfly Cuterebra angustifrons. Unpubl. Ph.D. dissertation, Univ. Michigan. $106 \mathrm{p}$

Bennett, G. F. 1955. Studies on Cuterebra emasculator Fitch 1856 (Diptera: Cuterebridae) and a discussion of the status of the genus Cephenemyia Ltr. 1818. Can. J. Zool. 33: 7598.

1972a. Further observations on Cuterebra emasculator (Diptera: Cuterebridae). Can. J. Zool. 50: 861-64.

$1972 \mathrm{~b}$. Observations on the pupal and adult stages of Cuterebra emasculator Fitch (Diptera: Cuterebridae). Can. J. Zool. 50: 1367-72.

1973. Some effects of Cuterebra emasculator Fitch (Diptera: Cuterebridae) on the blood and activity of its host, the eastern chipmunk. J. Wildl. Dis. 9: 85-93.

Cameron, T. W. M. 1956. Parasites and parasitism. John Wiley \& Sons, Inc., New York. 322 p.

Capelle, K. J. 1971. Myiasis. p. 279-305. In: Davis, J. W. \& R. C. Anderson, eds., Parasitic diseases of wild animals. Iowa State Univ. Press, Ames.

Catts, E. P. 1965. Host-parasite interrelationships in rodent bot fly infections. Trans. No. Am. Wildl. Nat. Res. Conf. 30: $184-96$.
Caullery, M. 1952. Parasitism and symbiosis. Sidgwick and Jackson Limited, London. 340 p.

Chandler, A. C. \& C. P. Read. 1961. Introduction to parasitology. John Wiley \& Sons, Inc., New York. 822 p.

Cheng, T. C. 1973. General parasitology. Academic Press, New York. 965 p.

Childs, H. E., Jr \& G. E. Cosgrove. 1966. A study of pathological conditions in wild rodents in radioactive areas. $\mathrm{Am}$. Midl. Nat. 76: 309-24.

Clough, G. C. 1965. Physiological effect of botfly parasitism on meadow voles. Ecology 46: 344-46.

Dalmat, H. T. 1942. A new parasitic fly (Cuterebridae) from the northern white-footed mouse. J. N.Y. Entomol. Soc. 50: 45-59.

Dunaway, P. B., J. A. Payne, L. L. Lewis \& J. D. Story. 1967. Incidence and effects of Cuterebra in Peromyscus. J. Mammal. 48: $38-51$.

Fitch, A. 1857. Third report on the noxious and other insects of the state of New York. Trans. N.Y. State Agric. Soc. 16: 315-490.

Forbes, R. B. 1966. Studies of the biology of Minnesotan chipmunks. Am. Midl. Nat. 76: 290-308.

Goertz, J. W. 1966. Incidence of warbles in some Oklahoma rodents. Am. Midl. Nat. 75: 242-45.

Hensley, M. S. 1976. Prevalence of cuterebrid parasitism among woodmice in Virginia. J. Wildl. Dis. 12: 172-79.

Hunter, D. M., R. M. F. S. Sadleir \& J. M. Webster. 1972. Studies on the ecology of cuterebrid parasitism in deermice. Can. J. Zool. 50: 25-29.

Krull, W. H. 1969. Veterinary parasitology. Univ. Kansas Press, Lawrence. $599 \mathrm{p}$.

McKinney, T. D. \& J. J. Christian. 1970. Incidence and effects of botfly parasitism in the eastern chipmunk. J. Wildl. Dis. 6: $140-43$.

Noble, E. R. \& G. A. Noble. 1976. Parasitology: The biology of animal parasites. Lea \& Febiger, Philadelphia. 566 p.

Payne, J. A. \& G. E. Cosgrove. 1966. Tissue changes following Cuterebra infestation in rodents. Am. Midl. Nat. 75: 20513

Payne, J. A., P. B. Dunaway, G. D. Martin \& J. D. Story. 1965. Effects of Cuterebra angustifrons on plasma proteins of Peromyscus leucopus. J. Parasitol. 51: 1004-08.

Pidduck, E. R. \& J. B. Falls. 1973. Reproduction and emergence of juveniles in Tamias striatus (Rodentia: Sciuridae) at two localities in Ontario, Canada. J. Mammal. 54: 693707

Selander, J. A. 1961. Hematological values in deer mice in relation to botfly infection. J. Mammal. 42: 57-60.

Seton, E. T. 1920. Does the Cuterebra ever emasculate its host? J. Mammal. 1: 94-95

Sillman, E. I. 1955. Studies on the biology of a cuterebrid (Cuterebridae: Diptera) infesting Peromyscus leucopus noveboracensis Fisher, the white-footed mouse in southern Ontario. Entomol. Soc. Ont. Ann. Rep. 86: 89-97.

Smith, D. H. 1977. Effects of experimental bot fly parasitism on gonad weights of Peromyscus maniculatus. J. Mammal. 58: $679-81$.

Timm, R. M. \& E. F. Cook. 1979. The effect of bot fly larvae on reproduction in white-footed mice, Peromyscus leucopus. Am. Midl. Nat. 101: 211-17.

Wecker, S. C. 1962. The effects of bot fly parasitism on a local population of the white-footed mouse. Ecology 43: 561-65. 